\title{
Revisiting the relationship between product diversification and internationalization process in the context of emerging market MNES
}

Abstract. We examine the contingent effect of existing product diversification on the scope and speed of firms' subsequent internationalization. Understanding these effects is important because prior research on the product - geographic diversification relationship assumes that the relevant decisions are taken simultaneously. This assumption does not apply to firms that consider international expansion only after having grown domestically through product diversification. Drawing on and extending transaction cost logics, we argue that product-diversified firms following geographically diverse and rapid internationalization incur higher transaction costs and are thus less likely to do so. We also find that international experience plays a moderating role.

Keywords: Product diversification; internationalization speed; geographic diversification; international experience; retailers; Latin America 


\section{Introduction}

International business scholars have become increasingly interested in studying the relationship between product and geographic diversification. Research into this relationship regularly assumes that firms simultaneously determine product and geographic diversification (Geringer, Tallman, \& Olsen, 2000; Kumar, 2009; Mayer, Stadler, \& Hautz, 2015; Wiersema \& Bowen, 2008). At the same time, this research has paid comparatively little attention to the effect of firms' prior diversification on their subsequent diversification decisions, despite indications of path dependence related to firms' diversification strategies (e.g., Hashai \& Delios, 2012; Hitt, Hoskisson, \& Kim, 1997). Prior diversification is of particular importance when firm diversification has been constrained by the particular institutional context of their home country because this prior diversification affects firms' subsequent diversification.

Research on the internationalization of Latin American firms has stressed that due to their particular institutional context, the strategies of these firms differ from those of firms based in developed or other emerging economies in theoretically significant ways (Bandeira-de-Mello, Fleury, Aveline, \& Gama, 2016; Brenes, Montoya, \& Ciravegna, 2014; Ciravegna \& Brenes, 2014; Ciravegna, Lopez, \& Kundu, 2016; Cuervo-Cazurra, 2016; Dominguez \& Brenes, 1997). Specifically, as a result of the import substitution policies of many Latin American countries, firms in those countries were initially compelled to grow through product or conglomerate diversification in their home countries (see, for example, Casanova, 2009; Fleury \& Fleury, 2011).

When deciding how to expand internationally, these firms thus do not concurrently decide on their level of product diversification but determine their internationalization 
based on an existing level of product diversification. Yet, we know very little about the effect that product diversification has on the international expansion of mature, late internationalizing firms. Such an effect seems particularly likely when firms aim to grow overseas sales (rather than just source inputs) and when doing so through exports is not possible. Product diversification is thus likely to play a crucial role, especially in horizontal international expansion in the retail sector, where retailers aim to grow overseas sales and exporting is not an option (Alexander, Rhodes, \& Myers, 2011).

While an effect of product diversification on geographic diversification is thus particularly likely in the case of retailers, anecdotal evidence has also stressed the importance of time-based competition in retailing and how this is reflected in the often rapid internationalization of fashion retailers, such as Zara (Ghemawat \& Nueno, 2006; Quinn \& Falley, 2010), and hypermarket chains, such as Tesco and Carrefour (Coe \& Hess, 2005; Coe \& Wrigley, 2007; Lowe \& Wrigley, 2010). In addition to its effect on firms' geographic diversification, we investigate the extent to which product diversification affects the speed with which retailers expand overseas. In so doing, we answer calls for more analyses of internationalization speed, an under-researched facet of firms' internationalization process (Casillas \& Acedo, 2013). The first research question addressed in this study is thus how product diversification affects the internationalization process of Latin American firms in the retail sector.

Further, recent research into the relationship between product and geographic diversification has highlighted inconsistent findings with regard to the shape of this relationship (Hashai \& Delios, 2012; Mayer et al., 2015; Peng, 2001) and has called for more analysis of the roles of firm-level factors that might moderate this relationship (e.g., 
Kumar, 2009). We suggest that firms' prior international experience moderates the effect of product diversification on geographic diversification and internationalization speed because of the likely effect that international experience will have on the transaction costs associated with the internationalization of increasingly wide product ranges. The second research question we address in this study is thus the question of how firms' international experience moderates the effect of product diversification on Latin American retailers' internationalization process.

By addressing these two research questions from a transaction cost economics (TCE) perspective using data on the internationalization process of the largest Latin American retail MNEs over the 1998-2013 period, our study makes the following contributions to the literature. First, our study contributes to our understanding of the link between product diversification and geographic diversification by investigating situations in which firms do not concurrently determine product diversification and international expansion but in which institutional contexts have led to a historical bias in which firms grow through domestic product diversification rather than through international expansion. Accounting for the idiosyncratic situations of Latin American firms also allows us to contribute to our understanding of how, rather than why, these firms internationalize. Research on this issue remains scarce compared to research on the internationalization of firms from emerging economies in general (Bandeira-de-Mello et al., 2016; Carneiro \& Brenes, 2014; Cuervo-Cazurra, 2007; Cuervo-Cazurra, 2008; de Góes \& da Rocha, 2015; Lopez, Kundu, \& Ciravegna, 2009; Nicholls-Nixon, Castilla, Garcia, \& Pesquera, 2011). In so doing, we also respond to calls for more research into the link between product and 
geographic diversification in the context of firms that are not in advanced stages of internationalization (Mayer et al., 2015; Ramamurti, 2009).

Second, through the examination of the influence of product diversification on internationalization speed as an important, yet often neglected, facet of internationalization, we contribute to a more comprehensive understanding of firm internationalization and its antecedents. Considering the increasing interest of IB researchers in the concept of internationalization speed (Gonzalez-Perez, Manotas, \& Ciravegna, 2016; Jiang, Beamish, \& Makino, 2014; Mohr \& Batsakis, 2016; Vermeulen \& Barkema, 2002), we focus on examining a relationship that adds new knowledge to this stream of research and contributes to our understanding of this under-researched facet of firms' internationalization process in the context of firms from emerging economies.

Third, our study contributes to the clarification of the contingent nature of the effects of firms' product diversification on their geographic diversification (e.g., Kumar, 2009) and internationalization speed. Specifically, we enhance our understanding of the effects of product diversification on these firms' internationalization process by underlining the moderating effect of their international experience. By relating firms' international experience to the costs faced by highly product-diversified firms when diversifying internationally, we also contribute to the clarification of the boundary conditions of transaction cost logic in this particular context.

Finally, recent research has called for a greater focus on the industries of firms, given strong indications that internationalization patterns vary across industries (Brandl \& Mudambi, 2014; Cuervo-Cazurra \& Ramamurti, 2014a). Through our focus on the 
internationalization of Latin American retailers, we contribute to research that aims to clarify the role of industry-specific characteristics in the internationalization of Latin American firms (see, in particular, Alexander \& Silva, 2002; Bianchi, 2009; Brenes, Chattopadyay, Ciravegna, \& Montoya, 2014).

We structure our paper as follows. In the next section, we review prior research on the internationalization of Latin American firms before explaining the role of product diversification as an important growth strategy for Latin American firms. On this basis, we then draw on transaction cost logic to explain the effects of product diversification on the geographic diversity and speed of firm's internationalization and to argue for a moderating effect of firms' international experience. We then outline the research setting, context, measurements and empirical methodology of our study before presenting the results of our empirical analysis. After discussing our findings, we conclude by presenting our study's contributions to theory, managerial implications, limitations, and avenues for future research.

\section{Research on the internationalization of Latin American firms}

Despite the scarce scholarly attention that firms from Latin America have received compared to those from other emerging market regions (Fastoso \& Whitelock, 2011; Nicholls-Nixon et al., 2011), recent research has highlighted how the Latin American context makes the analysis of Latin American firms important from both a practical and theoretical perspective (Bandeira-de-Mello et al., 2016; Brenes, Montoya, et al., 2014; Ciravegna et al., 2016; Cuervo-Cazurra, 2016; Dominguez \& Brenes, 1997). Research has thus begun to pay more attention to the internationalization of Latin American firms, 
predominantly investigating a) the factors that allow or prevent Latin American firms from internationalizing, as well as b) the process through which Latin American firms expand overseas. However, as in research on the internationalization of firms from other emerging economies, which has so far focused on the first of these issues (Aulakh, 2007; Cuervo-Cazurra, 2016; Cuervo-Cazurra \& Ramamurti, 2014b; Luo \& Tung, 2007), we know comparatively little about the nature of the internationalization process of these firms.

Table 1 highlights some of the most important empirical studies on the internationalization of multilatinas (i.e., Latin American MNEs) based on the two aforementioned streams of research (for a comprehensive review of this literature, see Carneiro \& Brenes, 2014; Cuervo-Cazurra, 2016).

*** Insert table 1 here $* * *$

Research on the first stream of research, i.e., into the factors that allow or prevent multilatinas from expanding internationally has stressed the role of particular firm capabilities and resources that are necessary for Latin American firms to internationalize (Aulakh, Kotabe, \& Teegen, 2000; de Góes \& da Rocha, 2015; Haar \& Ortiz-Buonafina, 1995; Thomas, Eden, Hitt, \& Miller, 2007). For example, research finds that firms' experiential knowledge (de Góes \& da Rocha, 2015), ability to adapt their marketing mix (Aulakh et al., 2000), financial flexibility (Haar \& Ortiz-Buonafina, 1995), and country of origin (Fleury \& Fleury, 2014) affect whether Latin American firms expand internationally. Research in this first stream has studied firms in multiple sectors based on 
their membership in the group of the largest Latin American firms (Cuervo-Cazurra \& Dau, 2009a, 2009b; Dau, 2012, 2013; Thomas et al., 2007) or has focused on Latin American firms operating in the manufacturing sector (see, for example, de Góes \& da Rocha, 2015; Haar \& Ortiz-Buonafina, 1995). Prior research on Latin American retailers has focused on the process through which these firms internationalize (see below).

Research within this first theme of the literature has also investigated whether the particular characteristics of Latin American countries affect the degree to which these Latin American firms expand overseas (Ciravegna et al., 2016; Dominguez \& Brenes, 1997). This research has highlighted how high levels of political uncertainty, violence, excessive bureaucracy, and half-hearted and often reversed shifts in economic policy from import substitution to liberalization have stymied the international expansion of Latin American firms, both by restraining their ability and willingness to do so and by reducing the attractiveness of countries in the region as potential target markets (e.g., Carneiro \& Brenes, 2014; Ciravegna \& Brenes, 2016; Cuervo-Cazurra, 2016; Domiguez \& Brenes, 1997). For example, Anand et al. (2006) argue that a lack of economic openness restrained Latin American firms' international expansion and that economic liberalization then allowed those firms to expand internationally. Similarly, the findings by Del Sol and Kogan (2007) suggest that firms based in highly regulated countries are less likely to internationalize than firms that experience deregulation and liberalization in their home countries.

Moreover, the characteristics of Latin American financial systems, such as low savings rates, higher external debt service ratios and foreign exchange controls, led firms to grow through domestic product diversification because they restricted domestic firms' 
access to capital and foreign exchange necessary to internationalize their operations (Ciravegna, Fitzgerald, \& Kundu, 2013; Edmunds, 2007).

Further, compared to other emerging economies, particularly those in Asia, Latin American governments have, on the whole, been less keen to promote the international growth of domestic firms (Casanova, 2009; Fleury \& Fleury, 2011). Through import substitution policies and tariff barriers, government fostered national rather than international growth among domestic firms (Casanova, 2009). In various Latin American countries, such as Brazil, the subsidiaries of foreign MNEs were expected to play a central role in domestic economic development (e.g., Fleury \& Fleury, 2011). To enhance their competitiveness vis-à-vis foreign MNEs in their home markets, local firms adopted domestic diversification strategies to exploit cost advantages and their better knowledge of domestic market conditions (Grosse, 2007; Guillen, 2000).

Finally, the particular institutional contexts of Latin American countries are also reflected in firm ownership, with a high share of (partially) state- or family-owned businesses (Casanova, 2009; Fleury \& Fleury, 2011). Since (partially) state-owned firms are likely to follow government instituted import substitution policies, they are more likely to seek domestic rather than international growth. Firms under family control are more risk averse (Casanova, 2009), and in order to address and survive the economic and political instability that have traditionally characterized most Latin American countries, these firms were more thus likely to focus on less risky product line diversification rather than on more risky geographic diversification (Casanova, 2009; Ciravegna et al., 2013; Fracchia \& Mesquita, 2007). 
Prior research in this first stream thus highlights the role that the institutional environment of Latin America has played and led to a greater emphasis among firms in these countries on growth through (domestic) product diversification than on growth through international expansion. While research has begun to explore how structural reforms affect Latin American firms' overseas expansion (see, for example, CuervoCazurra \& Dau, 2009a; Dau, 2013; Dominguez \& Brenes, 1997), our understanding of how this idiosyncratic, context-bound domestic growth orientation of Latin American firms affects their international expansion remains limited.

A second and comparatively less-developed stream of research on multilatinas has investigated the process that multilatinas follow in international expansion. So far, this stream of research has focused on Latin American firms' choice of foreign (country) entry modes (Cuervo-Cazurra, 2008; Cyrino \& Barcellos, 2013; Gonzalez-Perez \& Velez-Ocampo, 2014; Vasquez-Parraga \& Felix, 2004). Much of this research, however, is based on the analysis of the internationalization of particularly prominent examples of multilatinas, such as Vale, CEMEX and Embraer (Casanova, 2009; Fleury \& Fleury, 2011; Goldstein, 2002; Lessard \& Lucea, 2009; Santiso, 2013). Most of the prominent examples of multilatinas operate in the manufacturing or natural resources sectors and comparatively less emphasis has been placed on the internationalization process of Latin American firms from other sectors, such as the retail sector. Exceptions are the study by Bianchi (2009), which examined the internationalization process of Falabella, a Chilean retailer, through a longitudinal case study; the study by Alexander and de Lira e Silva (2002) of the internationalization process of Chilean retailer Sodimac and Brazilian retailer O Boticario; and the study by Brenes et al. (2014), which studied the difficulties 
encountered by Pollo Campero, the Guatemalan fast food company, in successfully expanding into the US market.

Based on analyses of case studies, research in this second stream of research indicates that Latin American firms take a long time to become MNEs; that they focus on a range of four strategies in their internationalization (Cuervo-Cazurra, 2008); that there are three alternative sequences of value-added activities in the internationalization of these firms (Cuervo-Cazurra, 2007); and that Latin American firms tend to follow a gradual approach to internationalization and do not export immediately after birth (Lopez et al., 2009). Although scholars have also started to identify the factors shaping Latin American firms' internationalization process, such research remains scarce compared to that on the factors that determine whether Latin American firms internationalize. One noteworthy exception is Dib et al.'s (2010) analysis of Brazilian software firms, which identifies a number of firm and entrepreneur characteristics, such as a firm's innovativeness or an entrepreneur's international orientation, that affect these firms' internationalization process.

In sum, a review of the literature reveals two main themes related to the explanation of Latin American firms' internationalization and the process of this internationalization. Whereas significant progress has been made with regard to the first of these two themes (Cuervo-Cazurra, 2008), our understanding of the internationalization process of multilatinas remains limited. Additionally, existing research on the internationalization process of Latin American firms remains largely descriptive, limiting our knowledge of the drivers that shape the process these firms use to expand internationally. By analyzing how Latin American firms' level of product diversification affects their 
internationalization process in terms of geographic diversification and internationalization speed, we hope to help close this gap in the literature on Latin American firms.

\section{Theoretical background and hypothesis development}

\subsection{Product diversification, geographic diversification, and internationalization speed of retail multilatinas}

Drawing on transaction cost logic we suggest that retail multilatinas offering extensive portfolios of products will be faced with higher transaction costs when expanding overseas, and doing so rapidly, than multilatinas with narrow product portfolios. This increase in transaction costs occurs in a number of ways.

First, increasing product diversification will raise the transaction costs associated with gathering and analyzing information on overseas markets when considering geographic diversification. The services and retail sectors, in particular, are traditionally highly regulated given their importance to domestic economies, e.g., by providing a large number of jobs and meeting the basic needs of the population. However, in addition to variation of such regulation across countries (e.g., land use regulation and zoning), the level and nature of regulation also varies significantly across multiple lines, such as nonfood versus food retailing (Levy \& Weitz, 2008; Swoboda, Elsner, \& Olejnik, 2014). The volume of information that internationalizing retailers need to collect and assess when expanding overseas and, consequently, the transaction costs associated with expanding overseas increase with retailers' level of product diversification. Highly productdiversified firms are thus less likely to expand overseas than are firms with low levels of 
product diversification. Similarly, the retail market structures, customer demands and availability and quality of suppliers for retailers are likely to vary across product lines (Levy \& Weitz, 2008). For example, assessing demand and preferences for footwear requires different information than assessing demand and preferences for consumer electronics. Retailers with multiple product lines will thus be required to collect and assess a greater volume of information and thus face higher transaction costs than retailers with fewer product lines when diversifying internationally.

Second, as a result of potential differences such as regulations and consumer preferences across countries and product lines, retailers with multiple product lines will also be more likely to need to adjust product assortment, retail formats and store locations to the particular host country conditions (Bianchi, 2009; Levy \& Weitz, 2008; Oh, Sohl, \& Rugman, 2015). The resulting costs are higher for firms with many rather than few product lines, increasing the costs associated with internationalization of the former compared to the latter firms and making them less likely to expand internationally. Similarly, retailers with multiple product lines are more likely to need to transfer, adapt and develop their firm-specific advantages (FSAs). In the context of retail multilatinas, research suggests that these firms' capabilities relate to home country networks and marketing knowledge (Bianchi, 2009). The likelihood that such firm-specific capabilities developed in the home market need to be adjusted and therefore the cost of doing so will be greater for firms with multiple product lines than for firms with only a few.

Third, the above-mentioned additional costs are recurring because retailers will have to monitor changes in overseas regulations, supplier availability and quality and consumer preferences on an on-going basis (Levy \& Weitz, 2008). Because of the 
differences across product lines, these monitoring costs will be higher for firms that operate internationally in multiple product lines. In addition, retailers with multiple product lines will need to monitor the activities of a larger number of competitors overseas compared to firms with a narrow product range (Oh, Sohl, \& Rugman, 2015). As a result, retail firms with high levels of product diversification are less likely to diversify internationally compared to retail firms with low levels of product diversification.

Fourth, retailers internationalizing with multiple product lines also face higher costs of coordinating and controlling an international store network and overseas supply chain (Narasimhan \& Kim, 2002). Prior research has used transaction cost logic to highlight the higher coordination and communication costs associated with expanding into new markets (Jones \& Hill, 1988; Williamson, 1985). Taking into account the greater complexity of coordinating and controlling foreign operations in not one but multiple product lines, the associated costs are likely to be higher for firms with multiple product lines. The higher costs of coordinating and controlling overseas operations for firms with multiple product lines will thus reduce the likelihood that these firms will diversify internationally.

Overall, we suggest that geographic diversification will be associated with higher transaction costs for firms with multiple product lines than for firms with only one product line. Importantly, we also suggest that these higher transaction costs of geographic diversification for firms with multiple product lines are likely to exceed the potential benefits of this diversification, such as (additional) economies of scale and scope (Dunning, 2000; Lu \& Beamish, 2004; Teece, 1986). We suggest that this is 
because of the sequential rather than concurrent nature of decisions about product and geographic diversification in our context, which differs from the common assumption in prior research that these decisions are made simultaneously (Hashai \& Delios, 2012). Concurrent decisions on product diversification and geographic diversification differ from the sequential decisions we are interested in that they offer more possibilities to align both types of growth in a way that reduces transaction costs, for example, by taking account of the idiosyncrasies of international markets when deciding on changes in product scope, and vice versa. Because of such alignment when concurrently deciding on product diversification and geographic diversification, firms are able to reduce the disadvantages and increase the advantages of both types of diversification. In contrast, the sequential nature of these decisions is common to the Latin American firms we are interested in and greatly reduces the potential for such an alignment resulting in comparatively more disadvantages and fewer advantages. We thus suggest that in the particular context of the (late) international expansion of Latin American firms, transaction cost logic implies a negative relationship between product and geographic diversification. Accordingly, we formulate the following hypothesis.

\section{H1: Product diversification will have a negative effect on Latin American} retailers' geographic diversification.

Based on a similar logic, we argue that high levels of product diversification will have a negative impact on the internationalization speed of multilatinas. Expanding overseas requires the collection and assessment of information, processes that require significant amounts of time (Mata \& Freitas, 2012). The more product lines a retailer has, the greater the amount of information that needs to be collected given the likely differences in the 
information needed to assess issues such as the regulations and consumer preferences for different product lines. As a result, the time required to make decisions about overseas expansion will increase with the number of product lines, slowing the internationalization process of these retailers. Similarly, adjusting products, services, and processes in line with the particular conditions of an overseas market requires time. Because they face potentially differing conditions across their multiple product lines, firms with multiple product lines are more likely to need to undertake such adjustments. The need to account for potentially differing conditions across various product lines is also likely to increase the time needed to transfer and adjust FSAs. The length of time needed for such adjustment will thus reduce the speed at which firms internationalize.

Although firms may attempt to speed up the processes of collecting and assessing information and adjusting products and services, firms with multiple product lines are also more likely to face time compression diseconomies than firms with fewer product lines. Such diseconomies refer to the increasing likelihood of inefficiencies when increasing a particular process - in our case, the international expansion of the firm (Dierickx \& Cool, 1989; Jiang et al., 2014; Vermeulen \& Barkema, 2002). Retailers that do not spend sufficient time collecting information about the respective regulations and consumer preferences of the host countries are more likely to make mistakes that lead to additional costs. Given the greater amount of information needed by retailers operating in multiple product lines, such firms are more likely to experience such time compression diseconomies and will thus internationalize at slower speeds than firms with fewer product lines (Wiersema \& Bowen, 2008). 
We thus suggest that product diversification will have a negative effect on retail firms' internationalization speed. Accordingly, we formulate the following hypothesis. H2: Product diversification will have a negative effect on Latin American retailers' internationalization speed.

\subsection{The moderating effect of international experience}

While firms with multiple product lines will face greater transaction costs when diversifying internationally and when doing so rapidly, we suggest that the level of such additional transaction costs will vary with firms' international experience.

First, internationally experienced firms will have greater levels of knowledge about host country conditions, reducing the amount of information that needs to be collected and assessed by firms when considering geographic diversification and rapid internationalization. The transaction costs resulting from the need to collect information about host country conditions for multiple product lines are thus reduced for internationally experienced firms, weakening the negative effect of product diversification on geographic diversification. Similarly, because of their existing knowledge of overseas markets, internationally experienced firms will require less time to collect and assess information about overseas markets and will be less likely to face diseconomies of time compression (Barkema, Bell, \& Pennings, 1996), weakening the negative effect of product diversification on internationalization speed.

Second, internationally experienced firms are more likely to be aware of adjustments that need to be made to their products, services and processes to operate overseas, and may have already developed the mechanisms for doing so. Research has linked international experience with the level of firms' absorptive capacity (Cohen \& Levinthal, 
1990; Eriksson \& Chetty, 2003; Eriksson, Johanson, Majkgård, \& Sharma, 1997). Their comparatively greater absorptive capacity allows internationally experienced firms to access and absorb valuable local information from local marketing agencies, suppliers, or customers at lower costs and more rapidly than firms with low levels of absorptive capacity. International experience will thus allow retailers to reduce both the transaction costs associated with and time required to make such adjustments, thus reducing the strength of the negative effects of product diversification on geographic diversification and internationalization speed.

Third, international experience can reduce the degree to which firms' FSAs are location bound (Clarke, Tamaschke, $\&$ Liesch, 2013), since these FSAs are more likely to have been developed accounting not only for the conditions and requirements in the domestic market but also for those in overseas markets. International experience thus reduces the costs associated with and time required for transferring, adapting and exploiting these FSAs when diversifying into overseas markets. Diversified firms with international experience will thus face comparatively lower transaction costs than diversified firms without such experience. Further, even in cases where firms' FSAs are location bound, internationally experienced firms will face lower costs and be quicker to develop the FSAs needed to expand internationally with a diversified product portfolio than firms without such experience. This is because internationally experienced firms have greater knowledge of the requirements and conditions of overseas markets and are more likely to know what works and what does not in a particular market, ensuring that their FSAs remain a source of competitive advantage in overseas markets (Bianchi, 2009). International experience will thus weaken the negative effect of product 
diversification on geographic diversification and internationalization speed because diversified firms with international experience will face lower transaction costs when internationalizing than their less-experienced counterparts who will face higher transactions costs resulting from additional search and information gathering activities.

We thus suggest that international experience reduces the transaction costs incurred by retailers with multiple product lines when diversifying internationally or internationalizing rapidly. The effect of product diversification on Latin American retail firms' geographic diversification and internationalization speed will thus be moderated by their international experience. Accordingly, we formulate the following hypotheses.

H3: International experience will attenuate the negative relationship between product diversification and Latin American retailers' geographic diversification.

H4: International experience will attenuate the negative relationship between product diversification and Latin American retailers' internationalization speed.

Figure 1 summarizes the hypothesized relationships graphically.

$$
\text { *** Insert Figure } 1 \text { here } * * *
$$

\section{Data and methods}

\subsection{Sample}


Our sample consists of retail multilatinas. Revenues in the Latin American retail sector have shown a compound annual growth rate of $13.4 \%$ over the period 2009-2014. Despite being late entrant MNEs (only 3.6\% of the world's 250 largest retailers originate in Latin America), Latin American retailers' share of overseas revenues to total revenues is among the highest in the world (the share of retail revenue from foreign operations in 2014 reached 25.2\% for Latin American retailers, which is among the highest in the world) (Deloitte, 2016).

The main source for our data is the Planetretail database. Recent empirical studies on the internationalization process in the retail sector have used this database (e.g., Gielens \& Dekimpe, 2007; Mohr, Fastoso, Wang, \& Shirodkar, 2014; Swoboda, Elsner, \& Olejnik, 2014). Planetretail provides longitudinal information on the largest retailers in the world that is not available from other databases. Given that our study focuses on firms originating in Latin America, we collected longitudinal information for the largest retailers (in terms of global sales volume) headquartered in Latin America, which also have an international presence (i.e., reported at least one year of international operations during the 16-year study period, 1998-2013). Given our interest in internationalization strategies, we do not include purely domestic retailers. We complement these data with country-level information from various sources to include control variables related to firms' home and host locations, including home market size, home market openness, and home institutional quality, as well as cultural, administrative and geographic distance, which have traditionally been argued to affect the process of internationalization.

After accounting for missing data, we are able to analyze 129 firm/year observations. Table 2 provides some basic information on the firms in our sample, including country of 
origin, foundation year, and average number of total and foreign outlets for two periods of examination, 1998-2005 and 2006-2013.

\footnotetext{
*** Insert Table 2 here ***
}

\subsection{Measures}

Our study uses two dependent variables, which each describe a unique facet of the firm internationalization process. First, in line with other studies (Chang \& Wang, 2007; Hitt et al., 1997), we measure geographic diversification using Jacquemin and Berry's (1979) entropy measure of diversification. This entropy measure is calculated as $\sum P_{i} \ln \left(1 / P_{i}\right)$, where $P_{i}$ is the percentage of sales in country $i$, and $\ln \left(1 / P_{i}\right)$ is the particular weight of each country. The advantage of using this measure is that it considers both the number of countries in which the firm operates as well as the sales reported for each country. Second, we measure internationalization speed as the average number of foreign outlets divided by the number of years since the firm's first international expansion. This measure has been widely used in several empirical studies investigating either the antecedents (Mohr \& Batsakis, 2014) or the outcomes of internationalization speed (Chang \& Rhee, 2011; Vermeulen \& Barkema, 2002).

We measure our independent and moderating variables as follows. In line with prior research (Li \& Tang, 2010; Qian, 2002; Wiersema \& Bowen, 2008) and following the same procedure as for the geographic diversification variable, we measure product diversification using Jacquemin and Berry's entropy measure of diversification (Jacquemin \& Berry, 1979). This provides a reliable index regarding the level of diversity 
in a retailer's product lines ${ }^{1}$. The product categorization is taken from the Planetretail database and ranges from 1 to 12 product lines (e.g., automotive products, clothing, footwear, jewelry, consumer electronics) for each retailer.

We follow prior studies and measure the international experience of a firm as the cumulative number of years in all foreign markets of operation since a firm's first international expansion (e.g., Mohr et al., 2014) based on the assumption that a long history of overseas operations will have allowed firms to accrue experiential knowledge (e.g., Clarke, Tamaschke, \& Liesch, 2013). Our measure also takes into account the number of foreign countries, as well as the number of years that the firm has operated in these foreign countries ${ }^{2}$.

We include a number of control variables to account for the role of other firm- and country-level factors that have traditionally been argued to affect firm internationalization. Firm age is measured as the year of observation minus the year of inception. To measure the size of the firm, we use the market share of each retailer, which is measured as the worldwide (retail format) market share of the firm in a given year. We also include a dummy for the segment in which a retailer operates. This variable takes the value 1 when the firm's main revenue source is grocery retailing and 0 otherwise.

\footnotetext{
${ }^{1}$ From a measurement perspective, firms' total sales are used as the denominators in both our measure of product diversification and our measure of geographic diversification. This, however, does not imply that the two measures are highly correlated, which is borne out by the absence of a strong correlation between the two measures $(.347, p<.05)$. From a resource-based view perspective, one would expect a degree of interdependence between firms' product and geographic diversification (e.g., Hashai and Delios, 2012), whereas in our case, the correlation between the two paths is relatively weak, which may, of course, be due to our interest in sequential rather than concurrent product and geographic diversification. Further, the VIFs indicate no collinearity concerns associated with using both measures simultaneously.

${ }^{2}$ An alternative measure of international experience is the number of foreign countries in which a firm operates. In our case, due to very high correlations between this and the originally adopted measure, we used only the latter, although we conducted robustness checks using the former measure. These robustness checks produced very similar results.
} 
We also include several country-level variables to account for the substantial heterogeneity among Latin American countries in terms of market size, openness, and quality of regulatory institutions. Prior research has emphasized the role of home market characteristics in the international expansion of Latin American firms (Anand et al., 2006; Carneiro \& Brenes, 2014; Ciravegna \& Brenes, 2014; Ciravegna et al., 2016; Cuervo-Cazurra, 2016; Dominguez \& Brenes, 1997). Specifically, while home market size is generally seen as an important influence on firm internationalization, CuervoCazurra (2016) stresses the roles that openness and regulation quality play in firms' international expansion. We therefore control for home market size, measured as the home country's gross domestic product (GDP) divided by $10^{12}$; home market openness, using the Trade Openness index from the Indices of Economic Freedom compiled by the Heritage Foundation ${ }^{3}$ (e.g., Kafouros \& Aliyev, 2016); and home institutional quality, using the six indicators of governance and institutional quality suggested by the World Bank (that is, voice and accountability, political stability and absence of violence/terrorism, government effectiveness, regulatory quality, rule of law and control of corruption) (e.g., Hearn, 2015). We also include home country dummies as additional controls for the institutional heterogeneity in the sample firms' home countries.

Finally, following prior studies that stress the relative nature of country characteristics in addition to their absolute levels, we control for the average cultural, administrative, and geographic distance between a firm's home country and the countries in which the retailer has set up operations. We calculate average cultural distance using Kogut and

\footnotetext{
${ }^{3}$ Trade freedom measures the openness of an economy to the import of goods and services from around the world and the ability of citizens to interact freely as buyers or sellers in the international marketplace. The measure considers restrictions on quantities, prices, regulatory restrictions, investment restrictions, customs restrictions and direct government interventions.
} 
Singh's formula (Kogut \& Singh, 1988) and Hofstede's four cultural dimensions (Hofstede, 2001). We measure average administrative distance using data on administrative distances between countries provided by the Penn Lauder Centre for International Business Education and Research (Berry, Guillén, \& Nan, 2010). To calculate average geographic distance, we used data on the latitude and longitude of the major city of each country (see, for instance, Hutzschenreuter, Kleindienst, \& Lange, 2014; Zaheer \& Hernandez, 2011). These data were taken from the French Research Centre in International Economics (CEPII).

\subsection{Methodology}

Our dataset is in panel (time-series) form. In general terms, the adoption of a Generalized Least Squares (GLS) estimator provides efficient estimates for such a dataset. However, our sample's dependent variables are idiosyncratic in terms of being constrained to positive numbers. Thus, we test our hypotheses using a random effects cross-sectional panel Tobit specification (Tobin, 1958), which allows us to control for other unobserved characteristics that might affect the dependent variables. A relative test confirms that the random effects cross-sectional panel Tobit model is more efficient than the pooled panel Tobit.

\section{Results}

Table 3 presents descriptive statistics regarding the destination of Latin American retail MNEs' outward investment by geographic region. The majority of outward investment $(63 \%)$ is oriented towards the home region of the sample, i.e., countries in Latin America. 
Additionally, more than one-quarter of outward investment is located in Africa and the Middle East (22.2\%) and in Australasia (7.4\%).

$$
\text { *** Insert Table } 3 \text { here *** }
$$

Table 4 presents descriptive statistics and correlations for all firms of our sample. The pairwise correlations between the variables do not indicate high correlations. However, in order to eliminate any potential multicollinearity issues that may arise due to the introduction of the interaction terms at a later stage, we mean-center the respective variables (Aiken \& West, 1991). The highest VIF score was below the threshold of 5.0, which is the most commonly used cut-off for possible multicollinearity.

*** Insert Table 4 here ***

Table 5 presents the results of our hypothesis tests. Models 1 and 3 report the results for the direct effect of product diversification on geographic diversification and internationalization speed, respectively.

*** Insert Table 5 here ***

Hypothesis 1 predicted that product diversification is negatively related to geographic diversification. The negative and significant coefficient on product diversification $(b=-$ $0.143, p<0.10$ ) in Model 1 (Table 5) supports this hypothesis. Specifically, the results 
indicate that all else being equal, a unitary increase in the level of product diversification will decrease the level of geographic diversification by an average of 0.143 .

Hypothesis 2 expected that product diversification would have a negative effect on internationalization speed. The negative and significant coefficient on product diversification $(b=-16.92, p<0.01)$ in Model 3 (Table 5) provides support for this hypothesis. In practical terms, our findings show that all else being equal, a unitary increase in the level of product diversification will decrease the speed of internationalization (i.e., the average number of foreign outlets with respect to the number of years since the firm's first international expansion) by 16.92 , on average.

Hypothesis 3 suggested a positive moderating effect of international experience on the relationship between product diversification and geographic diversification. The coefficient on the interaction between product diversification and international experience is positive and significant $(b=0.00311, p<0.01$, see Model 2, Table 5), indicating that international experience alleviates the negative relationship between product and geographic diversification. In terms of economic significance, this finding shows that all else being equal, an additional year of international experience will decrease the negative relationship between product and geographic diversification by 0.00293 , on average. Hence, hypothesis 3 is supported.

Model 4 examines hypothesis 4 and the moderating effect of international experience on the relationship between product diversification and internationalization speed. The coefficient of the interaction effect is positive and significant $(b=0.532, p<0.01)$, providing support for hypothesis 4 . Considering the economic significance of this finding, our result indicates that all else being equal, an additional year of international 
experience will decrease the negative relationship between product diversification and internationalization speed by 0.553 , on average.

\subsection{Sensitivity analysis}

To test the sensitivity of our results, we conducted various robustness checks. First, to further validate the consistency of the random effects cross-sectional panel Tobit model, we performed additional diagnostic tests. These tests indicated heteroskedasticity and autocorrelation (using the White and Wooldridge tests, respectively) as possible concerns for the validity of our results (Wooldridge, 2010). We thus used a Feasible Generalized Least Squares (FGLS) estimator, which provides an effective solution to both heteroskedasticity and first-order panel-specific autocorrelation (AR1). The results of the FGLS estimator are consistent and thus confirm the validity of the random effects crosssectional panel Tobit model ${ }^{4}$.

Second, we checked for possible endogeneity and sample selection bias that may arise from the relationship between product diversification and internationalization. Simply put, a firm's decision to internationalize is voluntary, and the level of product diversification might affect such a decision. Accordingly, we use a Heckman selection model in which we first implement a Heckman probit model to estimate the likelihood that a retailer has internationalized (Heckman, 1979). For this analysis, we gathered additional data corresponding to 21 non-internationalizing Latin American retailers for the same time period (1998-2013) and matched them to the existing sample of 12 internationalizing retailers. We then developed a dummy dependent variable taking the value 1 if the Latin American retail firm has internationalized and 0 otherwise. In the first

\footnotetext{
${ }^{4}$ The FGLS results are available from the authors upon request.
} 
stage, we used firm age, firm size, product diversification, industry and year dummies as predictors of the probability that a firm has internationalized. Then, we calculated the inverse Mills ratio $(\lambda)$ and included it in the second-stage Tobit models. The results are consistent for all four hypotheses ${ }^{5}$.

Third, although the relative tests confirmed the selection of the random effects Tobit specification, we estimate our models using a fixed effects Tobit specification ${ }^{6}$. The results are consistent.

Fourth, given the considerable inconsistency of the extant literature on the relationship between product and geographic diversification, we test for the potential curvilinearity of our hypothesized relationships. The inclusion of the quadratic term of the product diversification variable does not produce significant effects on either geographic diversification or internationalization speed ${ }^{7}$.

Finally, although the amount of sales that is reported in our study is strictly associated with retail product lines and, thus, no financial purchases/transactions are included in our data, some of the sample firms belong to a business group. These business groups offer a more diversified portfolio of services and products in the market. For example, members of such business groups may access services from other businesses in the group (e.g., banking services, loans, credit cards) to internationalize more rapidly. We thus included a

\footnotetext{
${ }^{5}$ We would like to thank one of the special issue workshop participants for suggesting this sensitivity test. The results of the Heckman two-stage estimation are available from the authors upon request.

${ }^{6}$ We used STATA statistical software to estimate our models. Generally, it is known that there is no command for a parametric conditional fixed effects Tobit model, as there does not exist a sufficient statistic allowing the fixed effects to be conditioned out of the likelihood. However, unconditional fixed effects Tobit models may fit the Tobit command with indicator variables for the panels, although such unconditional fixed effects estimates are sometimes biased. We have accordingly conducted the Tobit regression using the Tobit command and the suggested indicator variables for the panels. The fixed effect results are available from the authors upon request.

${ }^{7}$ We would like to thank one of the special issue workshop participants for highlighting this possibility. The results from the inclusion of the quadratic terms are available from the authors upon request.
} 
dummy variable taking the value 1 if a firm belongs to a business group and 0 otherwise. Including this dummy does not substantially alter our results ${ }^{8}$.

\section{Discussion and conclusion}

Our study of the contingent effect of product diversification on the internationalization process of Latin American retail MNEs was motivated by two main factors. First, prior research into the link between product diversification and geographic diversification assumes that these decisions are made concurrently, while the effect of product diversification on subsequent decisions on geographic diversification is not yet fully understood. In addition, prior empirical findings on the nature of the relationship between product and geographic diversification are inconsistent, underlining the likely existence of moderating factors. We suggest that given the particular institutional imprinting of Latin American firms (Bandeira-de-Mello et al., 2016; Cuervo-Cazurra, 2016), these firms provide a suitable setting for exploring these issues. By focusing on Latin American firms, our second aim was to contribute to our understanding of the internationalization of Latin American firms. We argued that while there has been progress in identifying the reasons these firms expand overseas, the factors that shape the internationalization process of these firms, particularly the geographic diversity and the speed of this process, remain underexplored (Cuervo-Cazurra, 2007; Nicholls-Nixon et al., 2011).

In Hypothesis 1, we proposed a negative relationship between product diversification and the subsequent geographic diversification of retail multilatinas. Although past

\footnotetext{
${ }^{8}$ We would like to thank the special issue workshop participants for highlighting this possibility. The results are available from the authors upon request.
} 
research has empirically examined the relationship between product and geographic diversification (e.g., Kumar, 2009; Wiersema \& Bowen, 2008), this research has not accounted for the potential sequential nature of these decisions (Hashai \& Delios, 2012; Hitt et al., 1997). We suggest that this is important because by concurrently deciding on product diversification and geographic diversification, firms are better able to align both types of growth in a way that reduces transaction costs, for example, by accounting for the likely transaction costs associated with internationalizing when deciding on changes in product scope. In contrast, firms that - due to historical or other reasons - determine geographic diversification only after having committed to product diversification will be faced with a more limited set of options to reduce the transaction costs associated with expanding internationally. While our finding for Hypothesis 1 is thus in line with prior research arguing for a negative relationship between (concurrent) product and geographic diversification (Meyer, 2006; Wiersema \& Bowen, 2008; Wolf, 1977), more research into the sequential relationship between these two types of diversification is needed. In our case, the sequential nature of expansion was largely due to the particular institutional context of the Latin American firms we studied, but future research may account for other drivers that affect the sequence of firms' diversification along different dimensions. Finally, our study also suggests that resource-based-view explanations of a positive link between product and geographic diversification (e.g., Geringer et al., 2000; Hitt, Hoskisson, \& Ireland, 1994) are likely to overestimate the possibility of exploiting firm resources and capabilities internationally in cases where firms do not determine product and geographic diversification concurrently. 
In Hypothesis 2, we suggested that product diversification negatively affects firms' internationalization speed. This finding complements the literature investigating the link between product and geographic diversification by accounting for a different facet of the internationalization process. Our finding indicates that product diversification decisions affect a wider range of firm decisions regarding their internationalization process. Focusing on the internationalization of Latin American retailers allows us to explore the interrelationships between product diversification and different facets of firm internationalization in a context in which mature firms that have traditionally focused on growth through domestic product diversification begin international expansion at a relatively late stage. Future research should investigate the issues addressed in our study in alternative contexts, particularly in contexts that have led to different growth trajectories of domestic firms, to improve our understanding of the role that (home country/region) institutional conditions play in the internationalization of firms (Casanova, 2009; Ciravegna et al., 2013; Cuervo-Cazurra, 2016; Dominguez \& Brenes, 1997; Edmunds, 2007; Fleury \& Fleury, 2011).

Given its likely performance effects (Casillas \& Moreno-Menéndez, 2013; Chang \& Rhee, 2011; Jiang, Beamish, \& Makino, 2014), there has been increasing interest in explaining firms' internationalization speed (Casillas \& Moreno-Menéndez, 2014; Mohr $\&$ Batsakis, 2014). This research has not yet accounted for the role of product diversification. Our finding on the negative effect of product diversification on internationalization speed thus complements existing research and underlines the importance of accounting for this factor when trying to understand why some firms internationalize more rapidly than others. 
Our findings with regard to the moderating effect of international experience (Hypotheses 3 and 4) underline the cost-reducing effect of international experience in the context of international expansion (e.g., Erramilli, 1991; Mohr \& Batsakis, 2014; Thomas et al., 2007). We argue that when internationalizing, highly diversified firms with international experience will face lower transaction costs than highly diversified firms without such experience. This will allow the former firms to engage in greater levels of geographic diversification and to internationalize more quickly than the latter firms. This finding thus underlines the importance of calls to account for moderating factors when explaining the relationship between product and geographic diversification (Kumar, 2009). Our empirical support for a moderating effect of international experience also highlights the need for further exploration of the boundary conditions of transaction cost logic in the context of firm internationalization. In transaction cost logic, most relevant variables are characteristics of a particular transaction (e.g., uncertainty, frequency), whereas our findings for Hypotheses 3 and 4 suggest that firm-level factors, such as international experience, influence the degree to which transaction characteristics lead to transaction costs for different firms.

The regression analysis offers interesting findings for the control variables reflecting the characteristics of our sample firms' home countries. Specifically, our results indicate that home market size has no effect on either geographic diversification or on the speed with which firms expand overseas. This is in line with the suggestion by Cuervo-Cazurra (2016) that market size does not necessarily play a key role in explaining the international expansion of Latin American firms and that other factors, particularly a country's openness, are more important. Interestingly, while we find no effect of a country's 
openness on the speed with which Latin American retailers expand overseas, we find that greater openness of a firm's home country reduces the level of Latin American retailers' geographic diversification, a finding that contradicts existing empirical research showing that financial market openness increases outward internationalization (Sun, Peng, Lee, \& Tan, 2015). This result may reflect the fact that trade policies toward the services industry are much more uncertain (Golub, 2009) or that our use of trade openness as a proxy for an economy's general openness may have little effect on firms' overseas expansion in the retail sector. An economy's openness to trade may, however, improve retailers' competitiveness in and thus their focus on the domestic market through better access to global supply chains. In addition, firms based in more open economies are also likely to face greater international competition in their home market and may thus focus on defending their home turf (Bianchi \& Ostale, 2006). Our results also indicate that while the quality of institutions in a firm's home country has no effect on its geographic diversification, the higher the quality of home country institutions, the slower their international expansion. A possible explanation for this finding relates to the escape motive for international expansion among firms from emerging economies (e.g., CuervoCazurra, 2012, 2016), that is, the weak home country institutions may drive firms to escape these institutions as quickly as possible.

Our results for the home country dummies indicate that being based in Brazil has a negative effect on both geographic diversification and internationalization speed. Although we find no effect for home market size (see above), this finding may be due to a combination of home market size and a significant change in economic policy in Brazil following the election of President Luiz Inácio Lula da Silva, which may not be captured 
adequately by our control variables. The results also indicate that Chilean MNEs are likely to internationalize more rapidly than their Brazilian and Mexican counterparts, although this effect disappears once interaction effects with firms' international experience are accounted for. This finding underlines how the improvements in financial development and the creation of a healthy capital market (Stallings \& Studart, 2006), as well as the strategic move towards more stable pro-market institutions (Levy \& Spiller, 1997) and less state intervention, have enabled and facilitated the international expansion of Chilean firms. Finally, our results indicate that being based in Mexico has a negative effect on firms' geographic diversification and no effect on firms' internationalization speed. This finding is likely to be due to Mexico’s NAFTA membership and Mexican retailers' predominant internationalization in the US. More specifically, due to the Free Trade Agreement and thus easier access to the US and Canadian markets, it is likely that Mexican firms have thus far engaged in limited - in terms of geographic scope internationalization, especially compared to other multilatinas.

Our controls for different types of distances indicate that cultural distance has a positive effect on internationalization speed. This finding is surprising but may reflect the fact that these countries share a common or similar language, religion and historical experiences. These factors may be more important than the cultural dimensions captured by Hofstede. The positive effect of administrative distance on firms' geographic diversification that we find may also be due to firms' escaping institutionally underdeveloped home countries by expanding overseas (Cuervo-Cazurra, 2012).

\subsection{Contribution to theory}


Our study's findings contribute to existing IB research in a number of ways. First, our study further develops research on the effects of product diversification on firms' internationalization process. Although past studies have empirically examined the relationship between product and geographic diversification (Hashai \& Delios, 2012; Mayer et al., 2015; Wiersema \& Bowen, 2008), this research has assumed that decisions about product and geographic diversification are made concurrently. We suggested that relaxing this assumption, which is necessary in the case of Latin American firms because of their home country institutional contexts, will require greater emphasis on the transaction cost effects of engaging in geographic diversification on the basis of existing product diversification. Our study also helps clarify the applicability of transaction cost logic to understanding the relationship between firms' product and geographic diversification in the case in which such decisions are not made concurrently (Geringer, Tallman, \& Olsen, 2000; Hashai \& Delios, 2012; Kumar, 2009; Mayer, Stadler, \& Hautz, 2015; Wiersema \& Bowen, 2008). By applying transaction cost logic to explain the growth of firms given the particular characteristic of Latin American firms, our study thus also contributes to the contextualization of transaction cost logic.

Second, our use of transaction cost logic to investigate the effects of product diversification on firms' internationalization speed contributes to the development of a theoretical explanation of both the comprehensive effect of product diversification on different facets of firm internationalization and the factors that affect firm decisions to internationalize rapidly rather than slowly. Our analysis indicates that the concept of speed can be usefully analyzed using transaction cost logic, particularly through the concept of time compression diseconomies. 
Third, by exploring how international experience moderates the effect of product diversification on both geographic diversification and internationalization speed, our study helps clarify the contingent nature of the effects of firms' product diversification on firms' geographic diversification (e.g., Kumar, 2009). By drawing on the TCE perspective to explain this moderating effect, we highlight the potentially important role of firm-level factors in influencing the level of transaction costs. Our findings in this respect underline the usefulness of enriching TCE-based explanations of firm internationalization that relate solely to the characteristics of transactions with explanations that integrate firm-level variables, such as international experience (e.g., Hennart, Sheng, \& Pimenta, 2015).

\subsection{Managerial implications}

Our study has a number of managerial implications. These implications are particularly useful for retail firms originating in Latin America, which wish to or have already internationalized their operations. Yet, we suggest that our findings are also relevant to firms based in other, mainly emerging, regions of the world.

First, utilizing the findings of this study, managers could assess the extent to which their firm's level of product diversification may facilitate or hinder their internationalization process. Latin American firms need to be aware of how their home country context has shaped their growth trajectory and how this trajectory affects their ability to diversify internationally and to internationalize rapidly. Managers of retail multilatinas need to be aware of how their firms' traditional focus on growth by adding product lines in their home country affects the costs of expanding internationally, for example, by increasing information and monitoring costs. Latin American retailers with 
multiple product lines also need to be aware of the potential diseconomies of time compression they are likely to face at higher internationalization speeds than are their competitors with a single or fewer product lines. While our focus was on Latin American firms, we suggest that firms from emerging economies in general are well-advised to account for how the particular institutional context in their home country has affected and continues to affect both their domestic and their international growth trajectories.

Second, our findings regarding the effect of international experience indicate that internationally experienced retail multilatinas will face a weaker trade-off between product diversification and geographic diversification/internationalization speed than their less experienced counterparts. Intuitively, this finding implies that the potential unavailability of valuable experience-related resources, such as knowledge of the foreign market and its institutional idiosyncrasies, is likely to hinder the attempts of such firms to offer both a diversified portfolio of products and to engage in wide/rapid internationalization at the same time. More internationally experienced firms are thus more likely to benefit from the relationship between product diversification and wide/rapid geographic expansion, whereas their less experienced counterparts need to pay more attention to properly balancing product and geographic diversification/internationalization speed.

Finally, while the institutional contexts of Latin American countries have a number of elements in common, there are also marked differences that affect the internationalization process of firms based in these countries. Specifically, our findings imply that Latin American retailers appear to use increasing openness in their home countries predominantly to cement their domestic positions through access to global supply chains. 
Thus, Latin American retailers should also consider the opportunities for international expansion offered by increasing openness. This seems to be of particular importance given our findings on the positive roles of both administrative and cultural distance. In a similar vein, the fact that each Latin American country is idiosyncratic in terms of its firms' internationalization behavior further validates the heterogeneous institutional context of the region. While Chilean retailers seem better able to cope with the internationalization process, Brazilian and Mexican retailers do not follow a similar pattern. Accordingly, these findings imply that the institutional context of a firm's home country has either induced or impeded the development of the ability to successfully operate in other countries within or outside Latin America and/or provided either strong or weak incentives to expand overseas.

\subsection{Limitations and areas for future research}

This study has several limitations. First, although we were able to gather data for enough years to conduct a longitudinal study, the size of the sample is limited to twelve firms. Although we included an additional twenty-one non-internationalizing Latin American retailers using a Heckman two-stage model to eliminate potential concerns related to sample selection bias, enlarging the dataset to include more firms was not possible due to our interest in firms that operate in at least one foreign market during the study period, which led to the small number of firms. As a result, the firms in our sample originated from only four Latin American countries.

Future research could build on our study in several ways. First, as our study answered recent calls for further testing of the relationship between product and geographic diversification in the context of EMNEs, future studies could test this relationship in 
other emerging regions to explore the role of home country institutions in shaping this relationship. We also suggested that the effects of product diversification on firms' internationalization are particularly pronounced in the case of horizontal international expansion in the retail sector in which firms cannot serve foreign markets through exports. It would thus be useful to investigate the effects of product diversification in other sectors both within Latin America and in other emerging economies. Second, despite the growing recognition of its importance for firm performance (e.g., Chang \& Rhee, 2011) internationalization speed continues to be one of the least researched facets of firms' internationalization process. Future research should thus build on existing work and further explore both the drivers and the consequences of internationalization speed in Latin American firms and in firms from other emerging economies. Third, to complement our results on the moderating role of firms' international experience, future studies should identify other firm characteristics that may moderate the relationship between product diversification and internationalization ${ }^{9}$.

\section{References}

Aiken, L. S., \& West, S. G. (1991). Multiple regression: Testing and interpreting interactions. Newbury Park, CA: Sage.

Alexander, N., Rhodes, M., \& Myers, H. (2011). A gravitational model of international retail market selection. International Marketing Review, 28(2), 183-200.

Alexander, N., \& Silva, M. de L. e. (2002). Emerging markets and the internationalisation of retailing: the Brazilian experience. International Journal of Retail \& Distribution Management, 30(6), 300-314.

Anand, J., Brenes, E. R., Karnani, A., \& Rodriquez, A. (2006). Strategic responses to economic liberalization in emerging economies: Lessons from experience. Journal of Business Research, 59(3), 365-371.

Aulakh, P., Kotabe, M., \& Teegen, H. (2000). Export Strategies and Performance of Firms From Emerging Economies: Evidence from Brazil, Chile, and Mexico. Academy of Management Journal, 43(3), 342-361.

\footnotetext{
${ }^{9} \mathrm{We}$ would like to thank one of the reviewers for highlighting this potential research examination.
} 
Aulakh, P. S. (2007). Emerging multinationals from developing economies: Motivations, paths and performance. Journal of International Management, 13(3), 235-240.

Bandeira-de-Mello, R., Fleury, M. T. L., Aveline, C. E. S., \& Gama, M. A. B. (2016). Unpacking the ambidexterity implementation process in the internationalization of emerging market multinationals. Journal of Business Research, 69(6), 2005-2017.

Barkema, H., Bell, J., \& Pennings, J. (1996). Foreign Entry, Cultural Barriers, and Learning. Strategic Management Journal, 17(2), 151-166.

Bianchi, C. (2009). Retail internationalisation from emerging markets: case study evidence from Chile. International Marketing Review, 26(2), 221-243.

Bianchi, C. C., \& Ostale, E. (2006). Lessons learned from unsuccessful internationalization attempts: Examples of multinational retailers in Chile. Journal of Business Research, 59(1), 140-147.

Brandl, K., \& Mudambi, R. (2014). EMNCs and catch-up processes: the case of four Indian industries. In A. Cuervo-Cazurra \& R. Ramamurti (Eds.), Understanding Multinationals from emerging markets (pp. 129-152). Cambridge: Cambridge University Press.

Brenes, E. R., Chattopadyay, A., Ciravegna, L., \& Montoya, D. (2014). Pollo Campero in the USA. Management Decision, 52(9), 1649-1679.

Brenes, E. R., Montoya, D., \& Ciravegna, L. (2014). Differentiation strategies in emerging markets: The case of Latin American agribusinesses. Journal of Business Research, 67(5), 847-855.

Carneiro, J., \& Brenes, E. R. (2014). Latin American firms competing in the global economy. Journal of Business Research, 67(5), 831-836.

Casanova, L. (2009). Global Latinas. Houndmills, Basingstoke: Palgrave Macmillan.

Casillas, J. C., \& Acedo, F. J. (2013). Speed in the Internationalization Process of the Firm. International Journal of Management Reviews, 15(1), 15-29.

Casillas, J. C., \& Moreno-Menéndez, A. M. (2014). Speed of the internationalization process: The role of diversity and depth in experiential learning. Journal of International Business Studies, 45(1), 85-101.

Chang, S.-J., \& Rhee, J. H. (2011). Rapid FDI expansion and firm performance. Journal of International Business Studies, 42(8), 979-994.

Chang, S. C., \& Wang, C. F. (2007). The effect of product diversification strategies on the relationship between international diversification and firm performance. Journal of World Business, 42(1), 61-79.

Ciravegna, L., \& Brenes, E. R. (2014). Learning to become a high reliability organization in the food retail business. Journal of Business Research, 69(10), 4499-4506.

Ciravegna, L., Fitzgerald, R., \& Kundu, S. K. (2013). Operating in Emerging Markets: A Guide to Management and Strategy in the New International Economy. Upper Saddle River, NJ: FT Press.

Ciravegna, L., Lopez, L. E., \& Kundu, S. K. (2016). The internationalization of Latin American enterprises-Empirical and theoretical perspectives. Journal of Business Research, 69(6), 1957-1962.

Ciravegna, L., Lopez, L. E, \& Kundu, S. K. (2014). Country of origin and network effects on internationalization: A comparative study of SMEs from an emerging and developed economy. Journal of Business Research, 67(5), 916-923.

Clarke, J. E., Tamaschke, R., \& Liesch, P. W. (2013). International experience in 
international business research: A conceptualization and exploration of key themes. International Journal of Management Reviews, 15(3), 265-279.

Coe, N. M., \& Hess, M. (2005). The internationalization of retailing: implications for supply network restructuring in East Asia and Eastern Europe. Journal of Economic Geography, 5(4), 449-473.

Coe, N. M., \& Wrigley, N. (2007). Host economy impacts of transnational retail: the research agenda. Journal of Economic Geography, 7(4), 341-371.

Cohen, W., \& Levinthal, D. (1990). Absorptive Capacity : A New Perspective on Learning and Innovation. Administrative Science Quarterly, 35(1), 128-152.

Cuervo-Cazurra, A. (2007). Sequence of value-added activities in the multinationalization of developing country firms. Journal of International Management, 13(3), 258-277.

Cuervo-Cazurra, A. (2008). The multinationalization of developing country MNEs : The case of multilatinas. Journal of International Management, 14(2), 138-154.

Cuervo-Cazurra, A. (2012). Extending theory by analyzing developing country multinational companies: Solving the Goldilocks debate. Global Strategy Journal, 2(3), 153-167.

Cuervo-Cazurra, A. (2016). Multilatinas as sources of new research insights: The learning and escape drivers of international expansion. Journal of Business Research, 69(6), 1963-1972.

Cuervo-Cazurra, A., \& Dau, A. L. (2009a). Structural Reform and Firm Exports. Management International Review, 49(4), 479-507.

Cuervo-Cazurra, A., \& Dau, L. A. (2009b). Promarket Reforms and Firm profitability in Developing Countries. Academy of Management Journal , 52(6), 1348-1368.

Cuervo-Cazurra, A., \& Ramamurti, R. (2014a). Introduction. In A. Cuervo-Cazurra \& R. Ramamurti (Eds.), Understanding Multinationals from emerging markets (pp. 111). Cambridge: Cambridge University Press.

Cuervo-Cazurra, A., \& Ramamurti, R. (2014b). Understanding multinationals from emerging markets. Cambridge: Cambridge University Press.

Cyrino, A. B., \& Barcellos, E. P. (2013). Cross-border M\&A and competitive advantage of Brazilian EMNEs. In P. J. Williamson, R. Ramamurti, A. Fleury, \& M. T. L. Fleury (Eds.), The competitive advantage of emerging market multinationals (pp. 191-219). Cambridge: Cambridge University Press.

Dau, L. A. (2012). Pro-market reforms and developing country multinational corporations. Global Strategy Journal, 2(3), 262-276.

Dau, L. A. (2013). Learning across geographic space: Pro-market reforms, multinationalization strategy, and profitability. Journal of International Business Studies, 44(3), 235-262.

de Góes, B. B., \& da Rocha, A. (2015). International expansion of Marcopolo (A): Adventures in China. Journal of Business Research, 68(2), 225-240.

Del Sol, P., \& Kogan, J. (2007). Regional competitive advantage based on pioneering economic reforms: The case of Chilean FDI. Journal of International Business Studies, 38(6), 901-927.

Deloitte. (2016). Global Powers of Retailing. Navigating the new digital divide.

Dib, L. A., Rocha, A., \& Silva, J. F. (2010). The internationalization process of Brazilian software firms and the born global phenomenon: Examining firm, network, and 
entrepreneur variables. Journal of International Entrepreneurship, 8(3), 233-253.

Dierickx, I., \& Cool, K. (1989). Asset stock accumulation and sustainability of competitive advantage. Management Science, 35(12), 1504-1511.

Dominguez, L. V., \& Brenes, E. R. (1997). The internationalization of Latin American enterprises and market liberalization in the Americas: A vital linkage. Journal of Business Research, 38(1), 3-16.

Dominguez, L. V, \& Sequeira, C. G. (1993). Determinants of LDC Exporters' Performance: A Cross-National Study. Journal of International Business Studies, 24(1), 19-40.

Dunning, J. H. (2000). The eclectic paradigm as an envelope for economic and business theories of MNE activity. International Business Review, 9(2), 163-190.

Edmunds, J. C. (2007). National financial systems in Latin America. Attributes, credit allocation practices, and their impact on enterprise development. In R. Grosse \& L. . Mesquita (Eds.), Can Latin American Firms Compete? (pp. 309-339). Oxford: Oxford University Press.

Eriksson, K., \& Chetty, S. (2003). The effect of experience and absorptive capacity on foreign market knowledge. International Business Review, 12(6), 673-695.

Eriksson, K., Johanson, J., Majkgård, A., \& Sharma, D. (1997). Experiential Knowledge and Cost in the Internationalization Process. Journal of International Business Studies, 28(2), 337-360.

Erramilli, M. (1991). The Experience Factor in Foreign Market Entry Behavior of Service Firms. Journal of International Business Studies, 22(3), 479-501.

Fastoso, F., \& Whitelock, J. (2011). Why is so little marketing research on Latin America published in high quality journals and what can we do about it?: Lessons from a Delphi study of authors who have succeeded. International Marketing Review, 28(4), 435-449.

Fleury, A., \& Fleury, M. T. L. (2011). Brazilian Multinationals: Competences for Internationalization. Cambridge: Cambridge University Press.

Fleury, A., \& Fleury, M. T. L. (2014). Country of origin effects on internationalization: insights from Brazil. In A. Cuervo-Cazurra \& R. Ramamurti (Eds.), Understanding Multinationals from emerging markets (pp. 242-267). Cambridge: Cambridge University Press.

Fracchia, E., \& Mesquita, L. . (2007). Corporate Strategies of Business Groups in the Wake of Competitive Shocks: Lessons from Argentina. In R. Grosse \& L. . Mesquita (Eds.), Can Latin American Firms Compete? Oxford: Oxford University Press.

Geringer, J., Tallman, S., \& Olsen, D. (2000). Product and international diversification among Japanese multinational firms. Strategic Management Journal, 21(1), 51-80.

Ghemawat, P., \& Nueno, J. (2006). Case Zara, fast fashion. Boston, MA.

Gielens, K., \& Dekimpe, M. (2007). The entry strategy of retail firms into transition economies. Journal of Marketing, 71(2), 196-212.

Goldstein, A. (2002). EMBRAER: de campeón nacional a jugador global. Revista de La CEPAL, 77, 101-121.

Golub, S. S. (2009). Openness to foreign direct investment in services: an international comparative analysis. The World Economy, 32(8), 1245-1268.

Gonzalez-Perez, M. A., Manotas, E. C., \& Ciravegna, L. (2016). International SMEs 
from emerging markets - Insights from the Colombian textile and apparel industry. Journal of International Entrepreneurship, 14(1), 9-31.

Gonzalez-Perez, M. A., \& Velez-Ocampo, J. F. (2014). Targeting one's own region: internationalisation trends of Colombian multinational companies. European Business Review, 26(6), 531-551.

Grosse, R. (2007). The role of economic groups in Latin America. In R. Grosse \& L. . Mesquita (Eds.), Can Latin American Firms Compete? (pp. 29-44). Oxford: Oxford University Press.

Guillen, M. (2000). Business groups in emerging economies: A resource-based view. Academy of Management Journal, 43(3), 362-380.

Haar, J., \& Ortiz-Buonafina, M. (1995). The Internationalization Process and Marketing Activities. The Case of Brazilian Export Firms. Journal of Business Research, 32(2), $175-181$.

Hashai, N., \& Delios, A. (2012). Balancing growth across geographic diversification and product diversification: A contingency approach. International Business Review, 21(6), 1052-1064.

Hearn, B. (2015). Institutional influences on board composition of international joint venture firms listing on emerging stock exchanges: Evidence from Africa. Journal of World Business, 50(1), 205-219.

Heckman, J. J. (1979). Sample Selection Bias as a Specification Error. Econometrica, 47(1), 153-161.

Hennart, J.-F., Sheng, H. H., \& Pimenta, G. (2015). Local complementary inputs as drivers of entry mode choices: The case of US investments in Brazil. International Business Review, 24(3), 466-475.

Hitt, M., Hoskisson, R., \& Ireland, R. (1994). A Mid-Range Theory of the Interactive Effects of International and Product Diversification on lnnovation and Performance. Journal of Management, 20(2), 297-326.

Hitt, M., Hoskisson, R., \& Kim, H. (1997). International Diversification: Effects on Innovation and Firm Performance in Product-Diversified Firms. Academy of Management Journal, 40(4), 767-798.

Hofstede, G. H. (2001). Culture's consequences: Comparing values, behaviors, institutions and organizations across nations. Sage.

Jacquemin, A. P., \& Berry, C. H. (1979). Entropy Measure of Diversification and Corporate Growth. The Journal of Industrial Economics, 27(4), 359-369.

Jiang, R. J., Beamish, P. W., \& Makino, S. (2014). Time compression diseconomies in foreign expansion. Journal of World Business, 49(1), 114-121.

Jones, G. R., \& Hill, C. W. L. (1988). Transaction cost analysis of strategy structure choice. Strategic Management Journal, 9(2), 159-172.

Kafouros, M., \& Aliyev, M. (2016). Institutional development and firm profitability in transition economies. Journal of World Business, 51(3), 369-378.

Kogut, B., \& Singh, H. (1988). The Effect Of National Culture On The Choice Of Entry Mode. Journal of International Business Studies, 19(3), 411-432.

Kumar, M. (2009). The relationship between product and international diversification: the effects of short-run constraints and endogeneity. Strategic Management Journal, 30(1), 99-116.

Kumar, S. M. V. (2009). The Relationship Between Product and International 
Diversification: The Effecs of Short-run Constraints and Endogeneity. Strategic Management Journal, 30(1), 99-116.

Lessard, D., \& Lucea, R. (2009). Embracing risk as a core competence: The case of CEMEX. Journal of International Management, 15(3), 296-305.

Levy, B., \& Spiller, P. (1997). Regulations, Institutions and Commitment. Comparative Studies of Telecommunications. Cambridge: Cambridge University Press.

Levy, M., \& Weitz, B. . (2008). Retailing Management. New York: McGraw-Hill.

Li, H.-L., \& Tang, M.-J. (2010). Vertical integration and innovative performance: The effects of external knowledge sourcing modes. Technovation, 30(7-8), 401-410.

Lopez, L. E., Kundu, S. K., \& Ciravegna, L. (2009). Born global or born regional? Evidence from an exploratory study in the Costa Rican software industry. Journal of International Business Studies, 40(7), 1228-1238.

Lowe, M., \& Wrigley, N. (2010). Case study-Tesco: from domestic operator to multinational giant. In G. Johnson, R. Whitington, \& K. Scholes (Eds.), Exploring Strategy (9th ed., pp. 658-664). London: Pearson.

Lu, J., \& Beamish, P. (2004). International Diversification and Firm Performance: The SCurve Hypothesis. Academy of Management Journal, 47(4), 598-609.

Luo, Y., \& Tung, R. L. (2007). International expansion of emerging market enterprises: A springboard perspective. Journal of International Business Studies, 38(4), 481498.

Mata, J., \& Freitas, E. (2012). Foreignness and exit over the life cycle of firms. Journal of International Business Studies, 43(7), 615-630.

Mayer, M., Stadler, C., \& Hautz, J. (2015). The Relationship Between Product And International Diversification: The Role Of Experience. Strategic Management Journal, 36(10), 1458-1468.

Meyer, K. (2006). Globalfocusing: From Domestic Conglomerates to Global Specialists. Journal of Management Studies, 43(5), 1109-1144.

Mohr, A., \& Batsakis, G. (2014). Intangible assets, international experience and the internationalisation speed of retailers. International Marketing Review, 31(6), 601620.

Mohr, A., \& Batsakis, G. (2016). Internationalization Speed and Firm Performance: A Study of the Market-Seeking Expansion of Retail MNEs. Management International Review. http://doi.org/10.1007/s11575-016-0284-9

Mohr, A., Fastoso, F., Wang, C., \& Shirodkar, V. (2014). Testing the Regional Performance of Multinational Enterprises in the Retail Sector: The Moderating Effects of Timing, Speed and Experience. British Journal of Management, 25(S1), S100-S115.

Narasimhan, R., \& Kim, S. W. (2002). Effect of supply chain integration on the relationship between diversification and performance: evidence from Japanese and Korean firms. Journal of Operations Management, 20(3), 303-323.

Nicholls-Nixon, C., Castilla, J., Garcia, J. S., \& Pesquera, M. R. (2011). Latin America Management Research: Review, Synthesis, and Extension. Journal of Management, $37(4), 1178-1227$.

Oh, C. H., Sohl, T., \& Rugman, A. M. (2015). Regional and product diversification and the performance of retail multinationals. Journal of International Management, 21(3), 220-234. 
Peng, M. (2001). The resource-based view and international business. Journal of Management, 27(6), 803-829.

Qian, G. (2002). Multinationality, product diversification, and profitability of emerging US small- and medium-sized enterprises. Journal of Business Venturing, 17(6), 611633.

Quinn, T. F., \& Falley, J. M. (2010). Retail Global Expansion. MN.

Ramamurti, R. (2009). What have we learned about emerging-market MNEs? In R. Ramamurti \& J. . Singh (Eds.), Emerging multinationals from emerging markets (pp. 399-426). Cambridge: Cambridge University Press.

Santiso, J. (2013). The Decade of the Multilatinas. Cambridge: Cambridge University Press.

Stallings, B., \& Studart, R. (2006). Finance for development. Latin America in Comparative Perspective. Washington DC: The Brookings Institution.

Sun, S. L., Peng, M. W., Lee, R. P., \& Tan, W. (2015). Institutional open access at home and outward internationalization. Journal of World Business, 50(1), 234-246.

Swoboda, B., Elsner, S., \& Olejnik, E. (2014). How do past mode choices influence subsequent entry? A study on the boundary conditions of preferred entry modes of retail firms. International Business Review, 24(3), 506-517.

Teece, D. J. (1986). Transactions cost economics and the multinational enterprise An Assessment. Journal of Economic Behavior \& Organization, 7(1), 21-45.

Thomas, D. E., Eden, L., Hitt, M. A., \& Miller, S. R. (2007). Experience of emerging market firms: The role of cognitive bias in developed market entry and survival. Management International Review, 47(6), 845-867.

Tobin, J. (1958). Estimation of Relationships for Limited Dependent Variables. Econometrica, 26(1), 24-36.

Vasquez-Parraga, A. Z., \& Felix, R. (2004). Investment and marketing strategies of Mexican companies in the United States: Preliminary evidence. Thunderbird International Business Review, 46(2), 149-164.

Vermeulen, F., \& Barkema, H. (2002). Pace, rhythm, and scope: process dependence in building a profitable multinational corporation. Strategic Management Journal, 23(7), 637-653.

Wiersema, M., \& Bowen, H. (2008). Corporate diversification: the impact of foreign competition, industry globalization, and product diversification. Strategic Management Journal, 29(1), 115-132.

Williamson, O. (1985). The economic intstitutions of capitalism. New York: Free Press.

Wolf, B. M. (1977). Industrial Diversification and Internationalization: Some Empirical Evidence. The Journal of Industrial Economics, 26(2), 177-191.

Wooldridge, J. M. (2010). Econometric analysis of cross section and panel data. Boston, MA: MIT Press. 
Figure 1. Research model

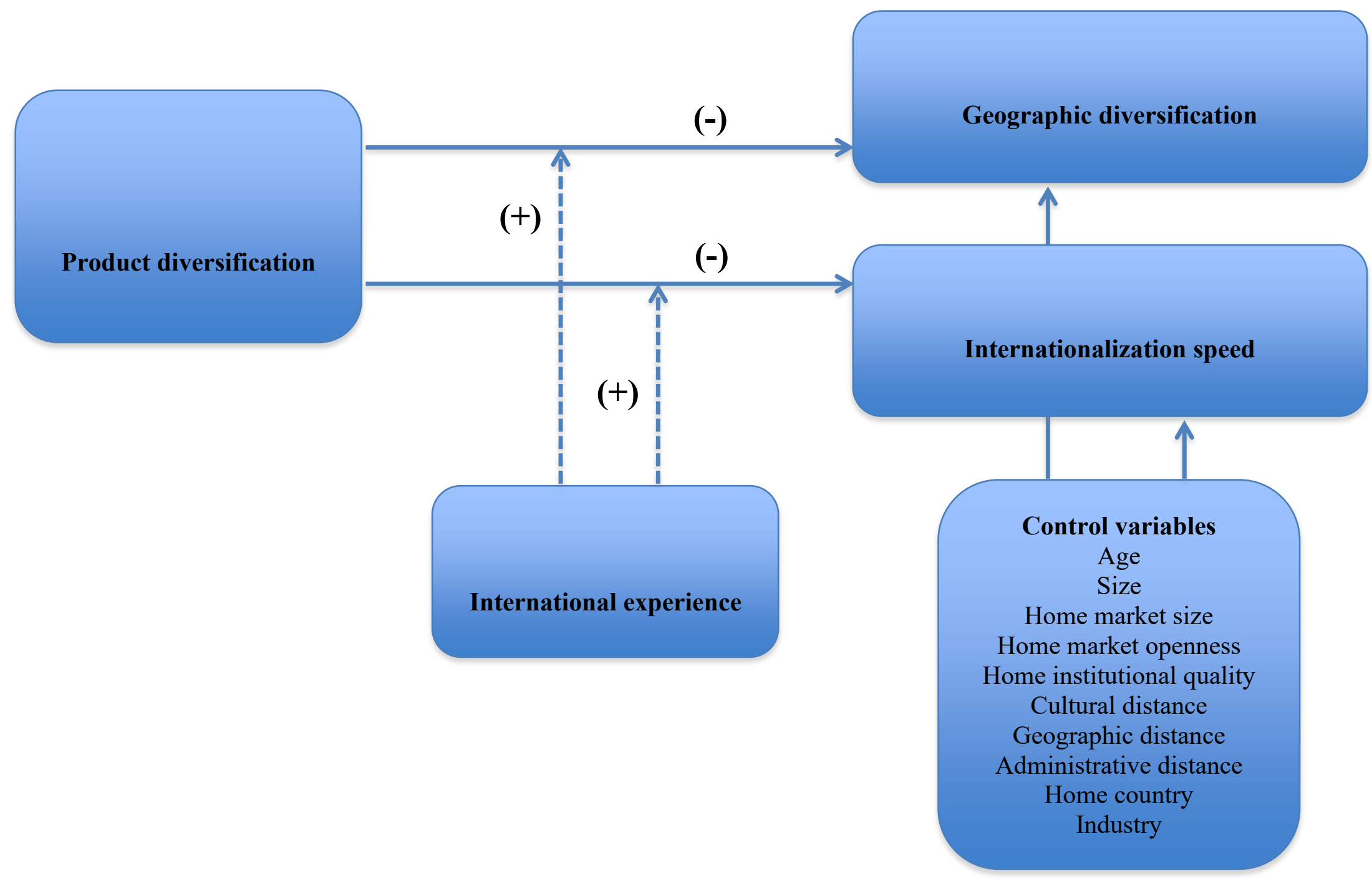


Table 1. Key empirical studies on the internationalization of Latin American firms

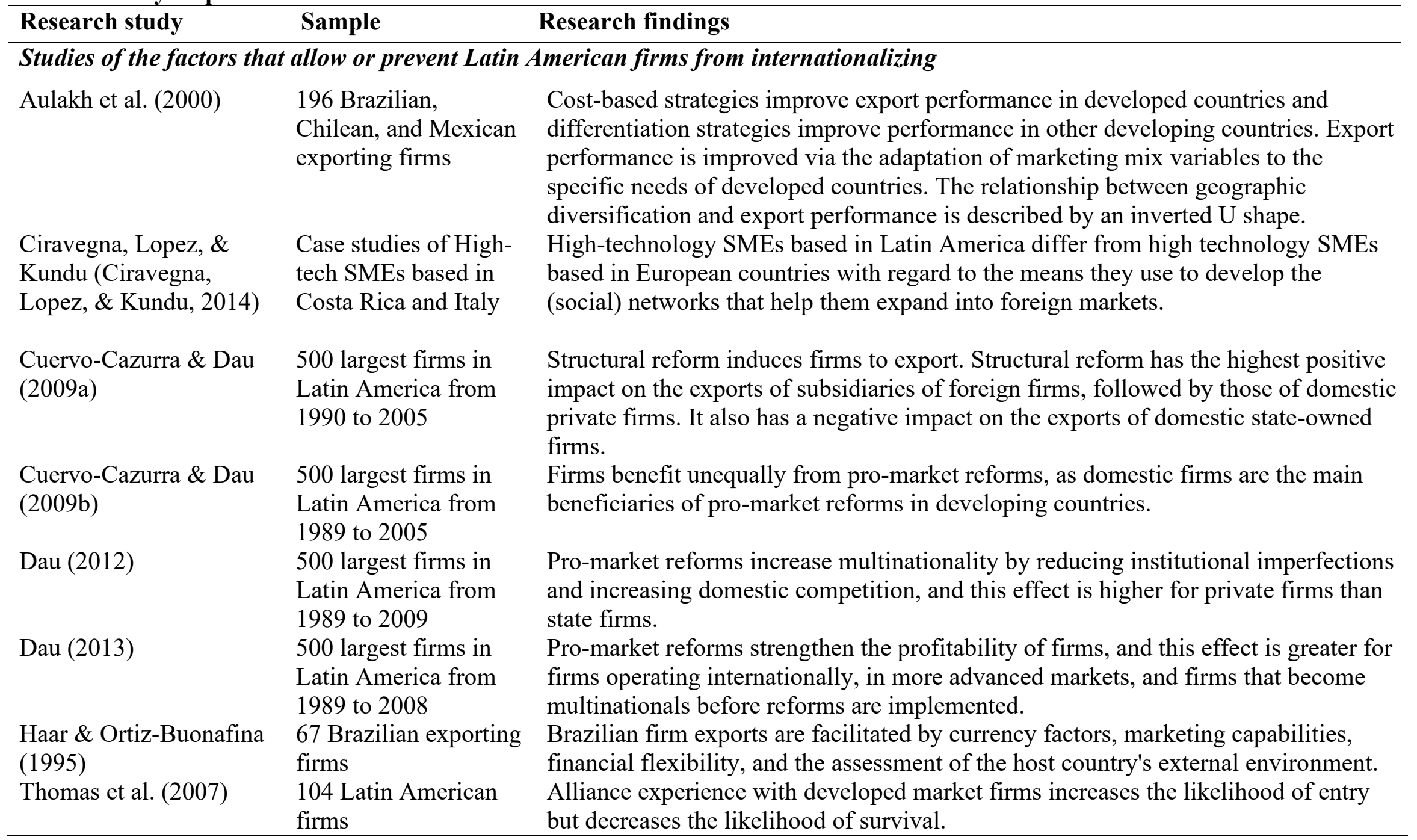




\section{Studies of the process through which Latin American firms expand overseas}

Bandeira-de-Mello et al. Single, in-depth case (2016)

Bianchi (2009)

Cuervo-Cazurra (2007)

Cuervo-Cazurra (2008)

de Góes \& da Rocha (2015)

Dib, da Rocha, \& da Silva (2010) study of a Brazilian MNE in the IT sector

Case study of the internationalization process of the Chilean retailer Falabella

20 case studies of some of the largest multilatinas

20 case studies of some of the largest multilatinas

Case study of 'Marcopolo', the largest Brazilian manufacturer of bus bodies. Examination of its first attempt to enter China.

79 Brazilian software firms
Choice of entry mode and organizational structures can alleviate the resource tradeoffs between exploration and exploitation in the process of firm internationalization.

There are particular capabilities and resources (including local and regional partnerships, organizational learning, innovation orientation, adaptation to the local markets, and an experienced management team) that are necessary for retailer multilatinas to internationalize and improve the likelihood of successful internationalization.

There are three alternative sequences of value-added activities as regards the multinationalization of multilatinas.

Multilatinas take a long time to become MNEs and are forced into multinationalization only after structural changes and reforms take place in their home country. Finally, the country selection of multinationalization is based on four distinct strategies.

Internationalization is associated with four complexities: 1 . Change in the nature of the firm's internationalization process (i.e., moved from psychically close markets to a psychically distant market. 2. Risks faced in the internationalization process. 3 . Advantages and disadvantages related to different entry modes in China. 4. The need to develop experiential knowledge in the Chinese market.

Certain firm and entrepreneur variables are associated with the type of internationalization process chosen. Network variables do not significantly differentiate between the born-global process and the traditional internationalization process. 
Dominguez \& Sequeira (1993)

Lopez et al. (2009)
253 exporters from

Costa Rica, El

Salvador, Guatemala,

Honduras, and

Panama

40 Costa Rican software born-globals
Identification of three patterns of performance. Each pattern is associated with a distinct strategy: low involvement-low volume-low content, price-cost-volume, and product-service quality orientation.

Costa Rican software providers follow a gradual approach to internationalization; they choose not to export immediately after birth.

Table 2. Information on sample retailers

\begin{tabular}{|c|c|c|c|c|c|c|c|}
\hline & \multirow{2}{*}{ Retailer } & \multirow{2}{*}{$\begin{array}{l}\text { Country } \\
\text { of origin }\end{array}$} & \multirow{2}{*}{$\begin{array}{c}\text { Foundation } \\
\text { year }\end{array}$} & \multicolumn{2}{|c|}{ Average total outlets } & \multicolumn{2}{|c|}{ Average foreign outlets } \\
\hline & & & & $1998-2005$ & 2006-2013 & $1998-2005$ & 2006-2013 \\
\hline 1 & Cencosud & Chile & 1960 & 167.29 & 929.43 & 97.57 & 611.43 \\
\hline 2 & Chedraui & Mexico & 1920 & 91.83 & 192.29 & 4.17 & 29.29 \\
\hline 3 & Coppel & Mexico & 1965 & $\mathrm{~N} / \mathrm{A}$ & 973.50 & $\mathrm{~N} / \mathrm{A}$ & 16.25 \\
\hline 4 & Falabella & Chile & 1889 & 108.29 & 406.71 & 17.57 & 176.00 \\
\hline 5 & FASA & Chile & 1969 & 828.00 & $1,232.14$ & 593.25 & 870.71 \\
\hline
\end{tabular}




\begin{tabular}{lllccccc}
6 & Grupo Carso & Mexico & 1903 & 503.00 & 418.86 & 245.20 & 20.57 \\
7 & Grupo Elektra & Mexico & 1950 & 920.60 & $1,134.29$ & 76.40 & 182.71 \\
8 & Grupo Famsa & Mexico & 1970 & 276.80 & 399.14 & 7.80 & 42.14 \\
9 & O Boticário & Brazil & 1977 & $2,291.20$ & $3,065.14$ & 65.40 & 74.57 \\
10 & Olimpica & Colombia & 1953 & 216.00 & 294.29 & 65.00 & 82.00 \\
11 & OXXO & Mexico & 1977 & N/A & $9,861.60$ & N/A & 25.60 \\
12 & SMU & Chile & 1961 & N/A & 730.00 & N/A & 20.33 \\
\hline
\end{tabular}

Table 3. Destination of Latin American investment by geographic region

\begin{tabular}{lcc}
\hline Region & $\begin{array}{c}\text { Number of } \\
\text { countries }\end{array}$ & \% \\
\hline Africa \& Middle East & 6 & $22.2 \%$ \\
Latin America & 17 & $63.0 \%$ \\
Australasia & 2 & $7.4 \%$ \\
Europe & 1 & $3.7 \%$ \\
North America & 1 & $3.7 \%$ \\
Total & 27 & $100.00 \%$ \\
\hline
\end{tabular}




\section{Table 4. Pairwise correlations and descriptive statistics}

\begin{tabular}{|c|c|c|c|c|c|c|c|c|c|c|c|c|c|c|c|c|c|}
\hline & & 1 & 2 & 3 & 4 & 5 & 6 & 7 & 8 & 9 & 10 & 11 & 12 & 13 & 14 & 15 & 16 \\
\hline 1 & Geographic diversification & 1 & & & & & & & & & & & & & & & \\
\hline 2 & Internationalization speed & 0.51 & 1 & & & & & & & & & & & & & & \\
\hline 3 & Product diversification & 0.35 & -0.23 & 1 & & & & & & & & & & & & & \\
\hline 4 & International experience & -0.15 & -0.13 & -0.55 & 1 & & & & & & & & & & & & \\
\hline 5 & Age & 0.23 & -0.31 & 0.62 & -0.10 & 1 & & & & & & & & & & & \\
\hline 6 & Size & 0.44 & 0.05 & 0.34 & 0.00 & 0.49 & 1 & & & & & & & & & & \\
\hline 7 & Home market size & -0.02 & 0.03 & -0.01 & 0.22 & 0.16 & 0.25 & 1 & & & & & & & & & \\
\hline 8 & Home market openness & 0.31 & 0.19 & 0.20 & -0.24 & 0.22 & 0.31 & 0.40 & 1 & & & & & & & & \\
\hline 9 & Home institutional quality & 0.68 & 0.51 & 0.01 & -0.05 & 0.11 & 0.15 & 0.00 & 0.28 & 1 & & & & & & & \\
\hline 10 & Cultural distance & 0.40 & 0.23 & 0.07 & 0.27 & 0.16 & 0.29 & 0.17 & 0.30 & 0.31 & 1 & & & & & & \\
\hline 11 & Geographic distance & -0.24 & 0.05 & -0.69 & 0.81 & -0.36 & -0.09 & 0.21 & -0.18 & -0.10 & 0.29 & 1 & & & & & \\
\hline 12 & Administrative distance & -0.27 & -0.19 & -0.49 & 0.64 & -0.30 & -0.03 & -0.05 & -0.31 & -0.35 & 0.14 & 0.70 & 1 & & & & \\
\hline 13 & Brazil & -0.36 & -0.19 & -0.56 & 0.82 & -0.29 & -0.13 & 0.00 & -0.43 & -0.14 & -0.02 & 0.74 & 0.75 & 1 & & & \\
\hline 14 & Chile & 0.70 & 0.54 & 0.05 & -0.12 & 0.12 & 0.12 & 0.00 & 0.24 & 0.97 & 0.20 & -0.16 & -0.45 & -0.21 & 1 & & \\
\hline 15 & Colombia & -0.09 & 0.08 & 0.08 & -0.19 & -0.04 & -0.17 & 0.00 & -0.29 & -0.38 & -0.49 & -0.21 & -0.33 & -0.09 & -0.21 & 1 & \\
\hline 16 & Mexico & -0.41 & -0.44 & 0.21 & -0.28 & 0.07 & 0.05 & -0.01 & 0.17 & -0.63 & 0.12 & -0.19 & 0.15 & -0.30 & -0.71 & -0.30 & 1 \\
\hline & Mean & 0.49 & 16.13 & 1.34 & 28.86 & 56.00 & 0.02 & 50.40 & 75.40 & 0.29 & 1.56 & $2,023.64$ & 6.71 & 0.08 & 0.33 & 0.08 & 0.50 \\
\hline & Std. dev. & 0.34 & 22.13 & 0.56 & 34.66 & 28.59 & 0.02 & 15.54 & 7.77 & 0.62 & 0.46 & $1,686.12$ & 5.04 & 0.28 & 0.47 & 0.28 & 0.50 \\
\hline & Min & 0.00 & 0.18 & 0.26 & 1.00 & 21.00 & 0.00 & 31.02 & 51.00 & -0.67 & 0.00 & 398.29 & 0.58 & 0.00 & 0.00 & 0.00 & 0.00 \\
\hline & Max & 1.45 & 102.29 & 2.10 & 169.00 & 124.00 & 0.09 & 75.38 & 88.00 & 1.25 & 2.54 & $7,504.93$ & 20.02 & 1.00 & 1.00 & 1.00 & 1.00 \\
\hline
\end{tabular}

Correlations with values great than $|0.15|$ are significant at the $5 \%$ level. 
Table 5. Random effects Tobit regression analyses of retail multilatinas' internationalization process

\begin{tabular}{|c|c|c|c|c|}
\hline & \multicolumn{2}{|c|}{ Geographic diversification } & \multicolumn{2}{|c|}{ Internationalization speed } \\
\hline & Model 1 & Model 2 & Model 3 & Model 4 \\
\hline \multirow[t]{2}{*}{ Product diversification } & $-0.143^{*}$ & $-0.246 * * *$ & $-16.92 * * *$ & $-33.69 * * *$ \\
\hline & $(0.0819)$ & $(0.0903)$ & $(6.535)$ & $(12.66)$ \\
\hline \multirow[t]{2}{*}{ International experience } & $-0.00368 * * *$ & -0.000252 & 0.110 & $0.667 * * *$ \\
\hline & $(0.00101)$ & $(0.00160)$ & $(0.0937)$ & $(0.203)$ \\
\hline \multirow[t]{2}{*}{ Product diversification $\mathrm{x}$ International experience } & & $0.00311 * * *$ & & $0.532 * * *$ \\
\hline & & $(0.00118)$ & & $(0.152)$ \\
\hline \multirow[t]{2}{*}{ Age } & 0.00350 & 0.00345 & -0.235 & -0.246 \\
\hline & $(0.00343)$ & $(0.00332)$ & $(0.154)$ & $(0.248)$ \\
\hline \multirow[t]{2}{*}{ Size } & $6.036 * * *$ & $5.393 * * *$ & $277.1 * * *$ & $199.1 * *$ \\
\hline & $(0.840)$ & $(0.850)$ & $(82.12)$ & $(86.41)$ \\
\hline \multirow[t]{2}{*}{ Home market size } & -0.00421 & -0.00636 & -1.363 & -1.589 \\
\hline & $(0.0159)$ & $(0.0155)$ & $(1.628)$ & $(1.455)$ \\
\hline \multirow[t]{2}{*}{ Home market openness } & -0.00311 & $-0.00334 *$ & 0.0791 & 0.0272 \\
\hline & $(0.00194)$ & $(0.00189)$ & $(0.197)$ & $(0.177)$ \\
\hline \multirow[t]{2}{*}{ Home institutional quality } & 0.115 & 0.163 & $-40.02 * *$ & $-32.69 * *$ \\
\hline & $(0.163)$ & $(0.160)$ & $(16.72)$ & $(14.98)$ \\
\hline \multirow[t]{2}{*}{ Cultural distance } & -0.0186 & 0.0546 & 9.322 & $20.73 * *$ \\
\hline & $(0.0759)$ & $(0.0778)$ & $(6.756)$ & $(9.221)$ \\
\hline \multirow[t]{2}{*}{ Geographic distance } & $2.43 \mathrm{e}-05$ & $2.61 \mathrm{e}-05$ & -0.00205 & -0.00153 \\
\hline & $(2.34 \mathrm{e}-05)$ & $(2.25 \mathrm{e}-05)$ & $(0.00200)$ & $(0.00208)$ \\
\hline \multirow[t]{2}{*}{ Administrative distance } & $0.0378 * * *$ & $0.0303 * * *$ & 0.396 & -1.015 \\
\hline & $(0.00583)$ & $(0.00639)$ & $(0.578)$ & $(0.791)$ \\
\hline \multirow[t]{2}{*}{ Brazil } & $-0.747 *$ & $-0.895 * *$ & $-40.52 *$ & $-60.13 *$ \\
\hline & $(0.428)$ & $(0.419)$ & $(22.29)$ & $(32.61)$ \\
\hline \multirow[t]{2}{*}{ Chile } & -0.0823 & -0.215 & $63.32 * *$ & 41.73 \\
\hline & $(0.399)$ & $(0.391)$ & $(28.23)$ & $(32.18)$ \\
\hline \multirow[t]{2}{*}{ Mexico } & $-0.584^{*}$ & $-0.584 *$ & -11.36 & -11.03 \\
\hline & $(0.334)$ & $(0.324)$ & $(14.60)$ & $(23.90)$ \\
\hline \multirow[t]{2}{*}{ Industry dummy } & -0.222 & -0.198 & 1.015 & 4.089 \\
\hline & $(0.215)$ & $(0.209)$ & $(9.108)$ & $(15.35)$ \\
\hline \multirow[t]{2}{*}{ Constant } & 0.853 & 1.012 & 102.4 & 121.6 \\
\hline & $(1.189)$ & $(1.158)$ & $(117.6)$ & $(106.8)$ \\
\hline Wald $\chi^{2}$ & $591.74 * * *$ & $630.72 * * *$ & $109.51 * * *$ & $129.85 * * *$ \\
\hline Random vs. Pooled model & $100.49 * * *$ & $94.69 * * *$ & $47.95 * * *$ & $60.58 * * *$ \\
\hline Number of firms & 12 & 12 & 12 & 12 \\
\hline N (firm/year observations) & 129 & 129 & 129 & 129 \\
\hline
\end{tabular}

Standard errors in parentheses. The analyses include year dummies. Colombia acts as the reference category for the home country dummies; * $\mathrm{p}<0.10$; * $\mathrm{p}<0.05 ; * * * \mathrm{p}<0.01$. 